\title{
Portrayals and Treatments of Women in Virginia Woolf's to The Lighthouse: A Critical Analysis
}

\author{
Varun Kumar Chaudhary \\ Bachelor of Arts (H) English \\ Student \\ K.R Mangalam University \\ Haryana, India \\ varunrogerfederer@gmail.com
}

Abstract

This paper means to address Virginia Woolf's own substitute her answer to "ladies can't paint, ladies can't compose", a reflection on the Victorian bias of the part of ladies in the family and society shared by both her people, Leslie and Julia Stephen. By connecting a nearby literary investigation with the latest mental basic examination, I contend that aside from the political, social and imaginative ramifications, Woolf's disposition to the Victorian generalizations identified with sexual orientation jobs convey a profoundly close to home message, being obviously affected and controlled by the relationship with her folks and her need to deceive rest some unsure issues concerning her status as a woman skilled worker.

This paper further means to investigate Woolf's 1926 novel, To the Beacon, which is, without a doubt, her most self-portraying novel. Lily Briscoe, the unmarried painter who at long last figures out how to conceptualize Woolf's vision toward the finish of the novel has a twofold mission in this novel. In the first place, she needs to determine her own weaknesses and come to harmony with the memory of the expired Mrs Ramsay, an image of the Victorian lady what's more, Julia Stephen's creative change personality. Second, she needs to associate with Mr Ramsay and demonstrate to herself that ladies can, in fact, paint. As she 
develops as a painter Virginia Woolf is defeating her resentment and dissatisfaction caused by the way that she didn't not find a way into the by and large acknowledged example of the lady's part in the public eye and in the everyday life, and particularly of the situation with ladies as specialists. By making quite possibly the most difficult books of the English Literature, Virginia Woolf likewise demonstrates to herself and to the perusers that ladies can, to be sure compose.

Keywords: Patriarchy, Feminism, Gender, Sexual Superiority, Society. Introduction

Virginia Woolf's tale, To the Lighthouse is a piece of writing which has a place with the artistic type of innovation and what imparts to Mrs. Dalloway furthermore, The Waves the peak of the author's imaginative powers. The entire novel is isolated into three sections. Section 1, "The Window", depicts a local gathering on the island of Skye. Prof. Ramsay and his better half are on vacation with their youngsters and a few companions. They have vowed to take their most youthful child James to see a beacon. The dad predicts unsatisfactory climate conditions also, the excursion is delayed. Section 2, "Time passes" explains how during the long stretches of war the house is left to residue and quietness and depression. At that point the family, without Mrs. Ramsay and two of the kids, returns. Part 3 "The Lighthouse" depicts the visit to the beacon after the death of the long time. The peaceful, proficient and insightful character of Mrs. Ramsay has a comparable situation in this novel to that of Clarissa Dalloway in Mrs. Dalloway. The characters battle to bring meaning also, request to the disorder of their lives. Woolf picked an mysterious storyteller who talks as an outsider looking in what's more, depicts the characters and activities emotionally, giving us understanding into the characters' sentiments. The account switches continually from the impression of one character to those of the following. The tone is beautiful, musical and innovative. The tale happens during the years promptly going before and following World 
War I on the Isle of Skye, in the Hebrides. In this paper, I might want to zero in on the two focal ladies in the story. I need to show that Virginia Woolf made two entirely unexpected characters yet with an intriguing and complex association and that Lily is a splendid illustration of innovation. The first is Mrs Ramsay, a lady as yet having a place with the Victorian age, the second, Lily Briscoe, an alleged "New lady". I need to analyse Mrs Ramsay and Lily by introducing likenesses and contrasts. I will look on changed viewpoints and uncover the mentality or the conduct of the ladies towards them. This is conceivable in view of the stream-of consciousness-strategy which Virginia Woolf picked for her novel. In this manner it is workable for us to get to know the most privet considerations of the characters. Furthermore, with Lily we discover a few hypotheses of women's liberation of those days. To the Lighthouse is an examination in human connections among a couple, mother and youngsters, love and cherished, man and the universe. Woolf was completely aware of the deficiency of human connections. Individuals appeared to her secluded from each other and correspondence between them is fractional, regularly unacceptable, and in some cases very mixed up. As said, the novel is separated into three segments, "The Window," "Time Passes," and "The Lighthouse". The centre part covers ten year of war. Mrs Ramsay bites the dust in this interval of time, which is the reason the concentration in the keep going part is on Lily, while the initial segment zeros in additional on Mrs Ramsay. There is not any more living character in fiction than Mrs. Ramsay. This is likely an excited evaluation yet there is at base a trace of validity in thinking about Mrs. Ramsay one of the generally ladylike of characters made in fiction. There have been ladies who are vain, pleased, class conscious, marvelous and otherworldly, and pious as well, as Mrs. Moore in Foster's A Passage to India or his Mrs. Ruth Wilcox in Howard's End. Mrs. Ramsay is the very apotheosis of a lady as the epitome of life, and supporting everything around. Virginia Woolf's To the Lighthouse is consequently an anecdotal model of her philosophies in regards 
to ladies in marriage and in the public eye. At the point when Woolf openly reported to female essayists that before they can compose they need to "murder the holy messenger in the house", she was totally serious, for this is actually what she does in this awesome work of writing that flawlessly analyses ladies' part under the umbrella of specific guideline.

Victim Feminism

In To the Lighthouse, we see customary use of women's liberation's tested. Woolf utilizes numerous various styles and procedures. While managing difficulties, portrayal and medicines of ladies; and the social connection between men, ladies, this is shown most powerfully inside the novel, To the Lighthouse. Mrs. Ramsay and Lily Briscoe are the two fundamental female characters in the novel(Chaudhary). The convictions of ladies characters are there to really focus on others wed individuals off and fit everybody. They are moreover there to ensure men, and to support their conscience. According to another perspective, Virginia Woolf pictures Lily as a free figure who appreciates investing energy by her own artistic creation, understanding verse what's more, isolating more than mingling, particularly as an enabled weapon against men. Yet, it very well may be attested that such disconnections incite questions in her head through the novel whether she understands what she wants or regardless of whether what she longs for. All such so called current characteristics saw in Lily blended with an undesirable misandry creating through her presence, transform her into favourable desolate lady is supportive of her own unadulterated autonomy notwithstanding her normal longing for hetero interests(Mill). As needs be, Lily Biscoe, as perhaps the most personally female personages among Virginia Woolf's books, could be viewed as both an extremist furthermore, a casualty women's activist figure since she is forfeited by a unbending male centric local area limited by forceful revolutionary women's activist philosophies which have supported her coasting endurance through an ocean of doubt and dualism, an ocean of doubt that continues to ask her who a lady is and what a lady ought to 
be. Thusly, Lily doesn't appear to swim deliberately aground, she only veers away coasting through the waves incited both by huge manly standards and furthermore by revolutionary nonconformist codes of woman's rights focusing on misandry as a methods for obstruction, while the most accessible log to save Lily from such wild waters is the thing that a judicious and valuable women's activist behaviour could assign, a behaviour which is excluded from any misandry and sexism(Munca).

Sexual Superiority

To the Lighthouse is a novel that is interested by ladies, as the points of view of Mrs. Ramsay and Lily are the most completely evolved accounts inside the content. Woolf's To the Light house poses the inquiry of sexuality of ladies, and questions the ladies' part inside the family. Lily addresses Woolf's 'optimal ladies' and Mrs. Ramsay in direct difference is depicted as the 'holy messenger of the house'. Woolf's exposition 'Callings for Women' assaults Victorian establishments, she expounds on 'executing the heavenly messenger of the house', which she effectively oversees through Mrs. Ramsay's passing in To the Lighthouse(ANSARI). Mrs. Ramsay is a result of the Victorian period, she is regarding sensitivity of feminity and Woolf, romanticize her and utilizations uninvolved language to depict her. Woolf's hypothesis in A Room of One's Own is critical on the grounds that it assists with getting her issues with sex and women's activist legislative issues set by man controlled societies.

"Regardless of whether these are genders in the brain relating to the two genders in the body, and regardless of whether they likewise need to be joined to get complete fulfilment and satisfaction... .In every one of us two force live, one male and female....It is destined to take care of business or lady straightforward as can be, one should be lady Manly or man Womanly" 
Woolf endeavours to show these distinctions through her depiction of Lily and Mrs. Ramsay, and again through Mr also, Mrs. Ramsay. Woolf accepted that man controlled society consistently attempted to quietness and quell ladies and ladies' encounters, this is the reason she rejects the arrangement of female qualities set by man centric society; pleasantness, unobtrusiveness, modesty and compliance... ., and shows these characteristics in direct difference to Mrs. Ramsay, and his manly judiciousness that has reason, request and clarity. In keeping with Woolf's 'Holy messenger of the House' figure, Mrs. Ramsay is extended more as an image as the 'earth mother' than as a person, as she is never called by her first name, she addresses the women's activist figure as she dismisses nonsensicalness, turmoil and discontinuity, which has come to address feminity(Kelley). Mrs. Ramsay's sex jobs are appeared in delicate reaction to Mr Ramsay; Mr Ramsay arises as a courageous dictator and seems to address the 'common male'. He is contrasted with sharp instruments, blades, hatchet, poker with which his child needs to hit him: "Had there been a hatchet convenient, or a poker, any weapon that would have slaughtered him, there and afterward James would have slaughtered him, there and afterward James would have held onto it" Patriarchy

Woolf exceptionally shows how the prioritization of the homegrown space has curbed ladies and kept them from partaking in ordinary exercises business, travel, work and training: This is seen in To the Lighthouse in the public and private domains; Mrs. Ramsay and Lily finds that mistreatment in the public domain is connected to that of the private. This shows how Woolf can manage material and monetary, notable conditions, which impact people lives, and their methods of seeing the world, their discernments and creative reaction's that vary(Chambers). Woolf examines sexual orientation and the force of people, she investigates the way in which we are built as gendered creatures, and how culture, and society, confines our activities, openings and discourse. Mrs. Ramsay discovers the quietness unnerving, as the 
clock halting appears to show her character falling separated. Mrs. Ramsay's desires must be accomplished at the point when she is dead, and through Mrs. Ramsay's demise, Lily accomplishes Mrs. Ramsay's oblivious longings(Chaudhary). In a man centric culture it has been denied to ladies. Ladies who are possessed by men are simple assets, having no influence over themselves and no real way to build up their own characters. Mrs. Ramsey needs individuals about her consistently in light of the fact that she has nothing disguised. She should make herself through others. She is continually bobbing off another person, ideally a male who has power, yet needs all her that power. Indeed, even today there are solid leftovers of man centric society overwhelming society. Men reliably move higher in administration and get more significant salary for equivalent positions. This epic shows the two men and ladies enduring and battling with cultural jobs. The response to the issue lies with the two sexual orientations. For as Mill states, "Ladies can't be required to give themselves to the liberation of ladies, until men in extensive number are set up to get together with them in the endeavour" (194). This isn't a female issue; it is a human issue(Mill).

Conclusion

Nineteenth-century extremist women's liberation dispatched an irregular development to alter dominant part of financial, political and social principles that had been set up by manly constitutions. In like manner, women's liberation was intended to sustain ladies socially just as actually, while it appears to have been caught in expansive current strategies which tended to amplify ladies and men's disparities from one viewpoint and reinforcing perspectives concerning ladies' suggested reliance on men - who have all smothered ladies as their casualties ever - on the other: a purported female opportunity in present day times. For example, ladies are permitted to legitimize furthermore, play their casualty part if there should arise an occurrence of assault could be both huge from one viewpoint and it could be viewed as decelerating on the other. It makes no sense to stand by and defraud ourselves 
doing nothing to battle savagery successfully. Present day extremist women's activists, who denounce any sort of manly follow through ladies' lives, have been endeavouring to shape ladies as interminable casualties of man centric social orders and this has been the supreme segregation essential women's activist researchers intended to wipe out As they at last arrive at the beacon, it closes on a lady accomplishing her vision with arranging the entanglements and assumptions for sexual orientation. The completion of To the Lighthouse, is huge comparable to the article little since Lily can't make oneself penances that Mrs. Ramsay made, she can't give the compassion to Mr. Ramsay that he feels is the ladies' job to accommodate a man. Since she can't and will not give compassion, she can accomplish clearness also, be narrow minded to finish something that interests her. She can do this since she will not adjust to her sex job, consequently appearing To the Lighthouse as Woolf leads to women's activist examination of a ladies' circumstance of the female experience One of the most conspicuous abstract figures of the 20th century, Woolf is broadly respected to her specialized advancements in the novel, most remarkably her improvement of stream of cognizance story. In To the Lighthouse, Woolf looked for grapple with her folks' smothering Victorian marriage and occasions of he own youth, just as to investigate such women's activist issues as the need, or even attractive quality, of marriage for ladies and the troubles for ladies in seeking after a profession in human expressions. "A striking blend of personal components, philosophical inquiries, and social worries, To the Lighthouse is by and large considered to be Woolf's most prominent anecdotal accomplishment" 
Works Cited

ANSARI, Dr. MOHAMMAD SHAUKAT. "VIRGINIA WOOLF'S TO THE LIGHTHOUSE AS A NOVEL FROM A POET’S PEN: A CRITICAL STUDY." Research Journal of English Language and Literature (2019): 9.

Chambers, R.L. Novels of Virginia Woolf. Ken Saunders (Stirling, ON, Canada): Oliver \& Boyd, Edinburgh, 1955, 2001.

Chaudhary, Sushma. "REPRESENTATIONS AND TREATMENTS OF WOMEN IN VIRGINIA." JOURNAL OF ENGLISH LANGUAGE AND LITERATURE (2018): 4.

Kelley, Alice van Buren. To the Lighthouse : the marriage of life and art / Alice van Buren Kelley. Boston: Twayne Publishers, 1987.

Mill, John Stuart. The Subjection of Women Second edition. London: Longmans, Green, Reader \& Dyer, 1869., 2014.

Munca, Daniela. "Virginia Woolf's Answer to "Women Can't paint,women can't wright into the light house." Journal of International Women's Studies (2009): 15. 